\title{
Pollinator Habitat Establishment after Organic and No-till Seedbed Preparation Methods
}

Gina M. Angelella

Department of Horticulture, Eastern Shore Agricultural Research and Extension Center, Virginia Tech University, 33446 Research Drive, Painter, VA 23420

\section{Megan E. O'Rourke ${ }^{1}$ \\ Department of Horticulture, Virginia Tech University, 301 Saunders Hall \#301, Blacksburg, VA 24061}

Additional index words. wildflowers, tillage, no-till, herbicide, bloom phenology, weed competition

\begin{abstract}
Establishing on-farm pollinator habitat can mitigate native pollinator and pollination ecosystem service declines, and federal programs are available to provide technical and financial assistance to farmers interested in habitat installation. Although sufficient seedbed preparation to limit weed competition is thought to be the most important step toward achieving good pollinator habitat establishment, preparation recommendations vary and studies have not investigated seedbed preparation techniques in the context of the U.S. Department of Agriculture (USDA) Farm Bill programs for pollinator conservation. To address this, we assessed the effects of two seedbed preparation methods, conventional inversion tillage and no-till with herbicide, on wildflower establishment and weed competition during the first year after planting. Experiments were conducted in Blacksburg, VA, and were replicated in 2015 and 2016. In addition, we tracked seedbed preparation methods and pollinator habitat establishment on seven farms located on the Eastern Shore of Virginia and Maryland in 2016. The wildflower mix consisted of nine species of forbs and two species of grasses: the forbs were black-eyed Susan (Rudbeckia hirta L.), partridge pea [Chamaecrista fasciculata (Michx.) Greene], plains coreopsis (Coreopsis tinctoria Nutt.), lanceleaf coreopsis (Coreopsis lanceolata L.), purple coneflower [Echinacea purpurea (L.) Moench], narrowleaf mountain mint (Pycnanthemum tenuifolium Schrad.), wild bergamot (Monarda fistulosa L.), Maximilian sunflower (Helianthus maximiliani Schrad.), and showy tickseed [Bidens aristosa (Michx.) Britton] or Indian blanket (Gaillardia pulchella Foug.); the grasses were splitbeard bluestem (Andropogon ternarius Michx.) and little bluestem [Schizachyrium scoparium (Michx.) Nash]. In the experiments, wildflower establishment was greater after no-till with herbicide than after tillage preparation $(2015: P=0.09 ; 2016: P=0.002)$. Predominating weed species varied by study, with more common lambsquarters (Chenopodium album L.) and hairy galinsoga [Galinsoga ciliata (Raf.) S.F. Blake] growth after tillage treatments, and more hairy vetch (Vicia villosa Roth) growth after no-till preparation. On-farm pollinator habitat establishment on the Eastern Shore was highly variable, but more wildflower forbs established after tillage-plus-herbicide than tillageonly seedbed preparations $(P=0.01)$. Across sites, we found a large degree of site-specific variation in wildflower establishment and predominant weed species.
\end{abstract}

Pollinator habitat installations can augment nutritional and habitat resources available for pollinators, thereby addressing native pollinator and honeybee declines and corresponding declines in pollination

Received for publication 22 Mar. 2017. Accepted for publication 19 June 2017

This research was supported by USDA Agroecosystem Management grant 11664133 and start-up funds provided to M.E. O'Rourke through the College of Agriculture and Life Sciences at Virginia Tech.

We thank Velva Groover, Chris McCullough, and Mike Graham for their contributions to data collection, and Sarah Karpanty and Alex Niemiera for preliminary review of the manuscript.

${ }^{1}$ Corresponding author. E-mail: megorust@vt.edu. and nutritional resources for native pollinators (Vaughan and Skinner, 2008, 2015).

Limiting weed competition is arguably the most important step to ensuring pollinator habitat establishment (Aldrich, 2002; Howell and Kline, 1992; Norcini and Aldrich, 2004; Perry, 2005), and adequate pollinator habitat seedbed preparation can be critical for ensuring sustained weed management throughout the pollinator establishment phase (Aldrich, 2002; Bartels, 1992; Martin, 1986; Wilson, 1992). Pollinator habitat installation guide recommendations for seedbed preparation methods vary (NRCS, 2007, 2012; Vaughan et al., 2013, 2014), but can generally be grouped into soil disturbance (in which topsoil is cultivated) or nondisturbance (no-till with herbicide application, solarization, burns, and/or grazing) practices (Aldrich, 2002).

A review of seedbed preparation studies for wildflower meadow establishment concluded that tilling multiple times, herbicide applications, or both generally provide better perennial weed management than solarization, burning, or grazing (Aldrich, 2002). Comparisons of tillage and herbicide seedbed preparations have generated mixed results. One study demonstrated that tillage yielded better wildflower establishment than herbicides after two years (Ahern et al., 1992), whereas other studies have indicated that both methods resulted in good weed control the first year of establishment (Corley, 1991; Corley et al., 1993). These contrasting results may depend on the specific wildflower species included in mixes as there can be species-specific responses to planting depth, soil bulk density, and critical weed-free periods (Hyder et al., 1955; Knezevic et al., 2002; Monsen and Stevens, 2004). In Virginia, NRCS agents do not recommend tillage because it is purported to stimulate weed growth (B. Glennon, personal communication), but this may be affected by site-specific weed seed bank communities (Chauhan et al., 2006; Oegema and Fletcher, 1972; Yenish et al., 1996).

To inform pollinator habitat establishment, we examined the effects of seedbed preparation in an experiment repeated over 2 years and in observational on-farm trials. This research is unique in that previous studies did not follow USDA seed mix recommendations specific to pollinator habitat establishment programs and were largely conducted on roadside embankments rather than farmland. Furthermore, this work is timely because the current body of peerreviewed research literature relating wildflower pollinator habitat establishment to seedbed preparation techniques is limited. We followed USDA NRCS recommendations for a pollinator habitat seed mixture appropriate for Virginia (B. Glennon, personal communication) that consisted of nine species of forbs and two species of grasses. The experiments tested the impacts of notill-plus-herbicide or conventional tillage seedbed preparation on wildflower establishment and weeds. We hypothesized that 
the establishment of smaller seeded species would be more negatively impacted by preparing the seedbed by tillage than larger seeded species, because of burial too deep for germination. In addition to the repeated experiment, we also tracked seedbed preparation and pollinator habitat establishment on seven farms on the Eastern Shore of Virginia and Maryland. Farmers individually chose how to prepare their pollinator habitat seedbeds with the input of NRCS technical advice; farm-specific constraints such a weed pressures and whether the farm was managed organically influenced the final plan for seedbed preparation.

\section{Materials and Methods}

We conducted three wildflower plot establishment studies to test the effects of seedbed preparation regime on pollinator habitat establishment and weed growth: two experiments at the Virginia Tech Kentland Agricultural Research Farm in Montgomery Co., VA (hereafter referred to as "Kentland $\# 1$ " and "Kentland \#2") in USDA Plant Hardiness zone $6 \mathrm{~b}$, and an on-farm study at seven locations across the Eastern Shore of Virginia and Maryland and in Virginia Beach (hereafter referred to as "Eastern Shore") in USDA Plant Hardiness zones 7b-8a (Supplemental Fig. 1). Comparisons of experimental designs are provided in Supplemental Table 1. Experiments Kentland \#1 and Kentland \#2 provided a controlled analysis of seedbed preparation treatments on pollinator habitat establishment, whereas the Eastern Shore experiment followed the seedbed preparation treatments used on six private farms and one university research farm to assess wildflower establishment. Collaborating Eastern Shore farmers specified the location and size of pollinator habitats on arable land, and independently prepared seedbeds before seeding using methods detailed in Supplemental Table 2. All sites included in the studies were deemed suitable for well-draining soil seed mixes. Kentland Agricultural Research Farm soil is classified as fine-loamy, mixed, active Ultic Hapludalfs (Hayter series). Soils at the Eastern Shore farms varied as detailed in Supplemental Table 2. Wildflower seeds were obtained from Roundstone Native Seed Company (Upton, KY) and Ernst Conservation Seeds (Meadville, PA) with pure live seeding rates differing slightly by experiment, depending on the quality of seed purchased (Supplemental Table 3).

Kentland \#1 was a randomized complete block design experiment replicated three times. Each block was divided into two treatment plots (six plots total-three till and three no-till), each measuring $4.6 \times$ $2.4 \mathrm{~m}$ and separated by $0.6 \mathrm{~m}$ buffers. Within each block, one plot received a no-till seedbed preparation treatment in which glyphosate was applied at $4.68 \mathrm{~L} \cdot \mathrm{ha}^{-1}$, and one was rotary power-tilled before wildflower seeding (Supplemental Table 1). Soil in all plots was packed with a tractor-pulled homemade water barrel roller before and after seeding and hand-broadcasted with a pollinator habitat seed mix on 24 Apr. 2015. The pollinator habitat seed mix contained two perennial grasses and nine forbs. The two grasses were splitbeard bluestem (Andropogon ternarius) and little bluestem (Schizachyrium scoparium). Of the forbs, three were annuals, one was biennial, and five were perennials, and all were selected to cover a bloom period from late spring to late summer. Annuals included plains coreopsis (Coreopsis tinctoria), partridge pea (Chamaecrista fasciculata), and showy tickseed (Bidens aristosa); the biennual was black-eyed Susan (Rudbeckia hirta); perennials included narrowleaf mountain mint (Pycnanthemum tenuifolium), lanceleaf coreopsis (Coreopsis lanceolata), wild bergamot (Monarda fistulosa), Maximilian sunflower (Helianthus maximiliani), and purple coneflower (Echinacea purpurea) (Supplemental Table 3). We counted wildflower stems within two randomly placed $0.25 \mathrm{~m}^{2}$ quadrants per plot three times in 2015 on: 3 June, early July (1, 2, 7, 8 July), and 28 Aug. We also collected all wildflower and total weed (broad leaf + grass) biomass within the $0.25 \mathrm{~m}^{2}$ quadrants during the early July 2015 sampling period, which we dried and weighed. We took stem counts of common weed species within quadrants during the first two vegetation surveys ( 3 June and early July) to assess weed recruitment by seedbed preparation treatment. We included hairy vetch (Vicia villosa), which had been planted as a cover crop the previous year, in weed stem counts.

Kentland \#2 repeated the treatments in Kentland \#1 and was a randomized complete block design experiment with four replicated blocks. Each block was divided into two treatment plots (eight plots total-four till and four no-till), each measuring $6.1 \times 2.7 \mathrm{~m}$. Similar to Kentland $\# 1$, one plot received a no-till seedbed preparation in which glyphosate was applied at $4.68 \mathrm{~L} \cdot \mathrm{ha}^{-1}$, and the other plot was rotary power-tilled (Supplemental Table 1). Plot soil was packed with a homemade water barrel roller pulled by tractor preand post-seeding, and was hand-seeded with the wildflower mix on 26 Apr. 2016 (Supplemental Table 3 ). The pollinator habitat mix differed from Kentland \#1 by one annual species, Indian blanket (Gaillardia pulchella), which replaced showy tickseed, but was otherwise identical in species composition. We counted wildflower stems three times by randomly dropping two $1 \mathrm{~m}^{2}$ quadrants into each plot in 2016 during mid-May $(13,14$, or 16 May), mid-June $(13,14$, or 16 June), and again between 31 Aug. and 9 Sept. We also collected all wildflower and total weed (broad leaf + grass) biomass within two randomly placed $0.25 \mathrm{~m}^{2}$ quadrants on 12 Sept. 2016, which we then dried and weighed. Stem counts of wildflowers in bloom and the percent weed cover of common weed species were also recorded during each of the three sample periods.

Eastern Shore farm sites ranged in seedbed area and preparation regime, and were selected for geographic range and farmer willingness to collaborate. Sites were located in Wicomico Co., MD, Accomack Co., VA, Northampton Co., VA, and Virginia Beach Co., VA (Supplemental Fig. 1). Mean habitat size measured $1257 \pm 412 \mathrm{~m}^{2}$ with a 557 $2023 \mathrm{~m}^{2}$ range. Two farms $(\mathrm{AC} 1, \mathrm{NH})$ used a combination of tillage-plus-herbicide treatment, and the remaining five farms used tillage only to prepare seedbeds. In particular, one farmer applied glyphosate at $1.2 \mathrm{~L} \cdot \mathrm{ha}^{-1}$ in early spring before planting, and the other applied $53.5 \mathrm{~g} \cdot \mathrm{ha}^{-1}$ thifensulfuron, $140 \mathrm{~g} \cdot \mathrm{ha}^{-1}$ flumiclorac, and $3.5 \mathrm{~L} \cdot \mathrm{ha}^{-1}$ glyphosate to the field in mid-August of 2015. Tillage methods varied and are specified in Supplemental Table 2. Other farm practices also varied, including the presence of a preceding winter crop cover, the number of years the site had been cropped during the previous 3 years, planting date, the number of early spring mows, time after planting to initial precipitation, and total number of tillage events (Supplemental Table 2). Soil in all sites was packed before and after seeding: three farmers pulled a $132 \mathrm{~cm}$ length roller filled with 379 L water (Tractor Supply Co., Pocomoke, MD) by tractor through the field, and four farmers used their personal cultipacker pulled by tractor. Planting dates ranged from 3 Mar. to 18 Apr. 2016. The wildflower mix was identical to Kentland \#2. We sampled wildflower habitats within $0.25 \mathrm{~m}^{2}$ quadrants dropped in each of three locations: within $2 \mathrm{~m}$ from the edge, a quarter of the total distance into the plot, and at the plot center. Wildflower stem counts were taken five times: mid-May to early June (16 May to 10 June), late June (20-28 June), late July (14-21 July), mid-August (16-18 Aug.), and late August to mid-September (23 Aug. to 15 Sept.). Percent bloom cover was also measured during each sample period, which was a visual estimate of percent flowering cover by species within each quadrant. During the last sample period, we collected all wildflower and total weed (broad leaf + grass) biomass in $0.25 \mathrm{~m}^{2}$ quadrants, dried and weighed them, and recorded predominant weed species.

Data analysis. We conducted all statistical analyses using JMP Pro v. 12 (SAS Institute Inc., 2016). We first tested the effects of seedbed preparation on wildflowers and weeds in Kentland \#1 and Kentland \#2 using general linear mixed models (GLMMs) with seedbed preparation as a fixed effect and block as a random factor. Response data were transformed as necessary to meet model assumptions of normality and homogeneity of variance. Total weed biomass in the Kentland \#2 experiment was log-transformed; pigweed (Amaranthus spp.) counts in the Kentland \#1 experiment as well as hairy galinsoga in the Kentland \#2 experiment were both square-root transformed. Hairy vetch, Pennsylvania smartweed (Polygonum pensylvanicum L.), and common lambsquarters data from the Kentland \#1 experiment were all transformed to presence or absence and fit to GLMMs with a binomial distribution and logit link function. To examine the 
overall effect of seedbed preparation on wildflower stem counts, data were summed over all wildflower species, averaged across quadrants and sample dates, and analyzed with Student's $t$ tests. We also used Student's $t$ tests to examine the species-specific effects of seedbed preparation on the stem counts of each individual wildflower species.

To explore how seedbed preparation affects the establishment of wildflowers with different seed sizes, we ran mixed model regression analysis. The response variable was the magnitude of change in stem counts between seedbed preparation treatments, and seed mass was the predictor variable. The magnitude of change for each species' stem counts was calculated as $\left[\left(\mu_{1}+0.01\right)-\right.$ $\left.\left(\mu_{2}+0.01\right)\right] /\left(\mu_{2}+0.01\right)$, where $\mu_{1}=$ stem count mean after no-till preparation and $\mu_{2}=$ stem count mean after tillage preparation. A value of 0.01 was added to treatment means before calculation to avoid a denominator of zero. The magnitude of stem count change was $\log +1$ transformed before analysis.

We conducted a number of statistical tests to compare wildflower stem counts and blooms among the different wildflower species in the three experiments. Significant differences in stem counts (averaged across sampling dates) among species were compared within each seedbed preparation treatment in Kentland \#1 and Kentland \#2 and across all farms in the Eastern Shore study using Tukey-Kramer honestly significant difference tests. For the Kentland \#2 experiment, we tested for variation in blooms among species by sample period using a repeated measures GLMM that included species as a fixed factor, date as a repeated measure with an AR1 covariance structure, and block as a random factor. Bloom stem counts were averaged over the two seedbed preparation treatments before analysis in the Kentland \#2 experiment.

For the Eastern Shore dataset, we determined the influence of a number of environmental and management factors on wildflower and weed establishment using general linear models. Before analysis, wildflower stem counts were averaged across quadrants and sample dates by farm whereas wildflower and total weed biomass were averaged across quadrants. The fixed factors that were tested included seedbed preparation (tillage-plusherbicide vs. tillage-only), presence or absence of winter cover crop, seedbed packing method (cultipacker or roller), number of years cropped during the past 3 years, planting date, days after planting to initial precipitation, and total number of seedbed preparation tillage events. Because of the large amount of among-site variability and the small sample size $(n=7)$, the factors were investigated individually.

\section{Results}

Although two grass species (splitbeard bluestem, little bluestem) were included in all three studies, we did not detect any establishment during vegetation surveys.
Thus, results pertain to wildflower forb establishment. Narrowleaf mountain mint was also present in all seed mixtures but not identified during vegetation surveys.

Kentland \#1 and Kentland \#2. There was a trend toward higher wildflower stem counts in no-till compared with tilled seedbeds in the Kentland $\# 1$ experiment $(P=0.09)$. In the Kentland \#2 experiment, total wildflower stem counts within plots with no-till preparations were significantly higher than in those with tillage $(P=0.002)$. Both wildflower biomass and total weed biomass were significantly higher under a no-till than a tilled seedbed preparation in the Kentland \#2 experiment $(P=0.003, P=0.04$, respectively), but not in the Kentland $\# 1$ experiment $(P=$ $0.7 ; P=0.8$, respectively) (Table 1 ). Stem counts of both Indian blanket and Maximillian sunflower were significantly higher in no-till than in tilled plots in Kentland \#2 and all individual species had higher stem counts, on average, in no-till than in tilled plots except for purple cone flower and lanceleaf coreopsis in the Kentland \#1 experiment (Table 2). Seed weight was not a significant predictor of the magnitude of the effect of tillage on wildflower stem counts in either study (2015: $P=0.25 ; 2016: P=0.19$ ). Black-eyed Susan, a biennial, had the highest overall stem counts in both Kentland studies.

Common weed species in Kentland \#1 included hairy vetch, common lambsquarters, pigweed, and Pennsylvania smartweed; common weed species in Kentland \#2 included hairy galinsoga and large crabgrass [Digitaria sanguinalis (L.) Scop.]. The abundance of two weed species, hairy vetch and common lambsquarters, differed significantly between seedbed preparation treatments in the Kentland \#1 experiment. Hairy vetch was present in a greater number of samples under the no-till treatment than the tilled treatment (no-till: present in 5/6 samples, tillage: present in 1/6 samples; $P=$ 0.02 ), whereas common lambsquarters was present in a greater number of tilled than notill treatment samples (no-till: present in 1/6 samples, tillage: present in 5/6 samples; $P=$ 0.02 ). The percent cover of Pennsylvania smartweed (no-till $2.0 \pm 1.4$, tillage $8.7 \pm$ $3.9 ; P=0.6$ ) and pigweed (no-till $13.3 \pm 4.4$, tillage $18.0 \pm 9.3 ; P=0.6)$ did not vary significantly by treatment in the Kentland \#1 experiment. In the Kentland \#2 experiment, hairy galinsoga percent cover was significantly greater under the tillage than the no-till treatment (no-till: $2.0 \pm 0.4$, tillage: $24.0 \pm$ 5.4; $P=0.0009$ ), and was inversely related to wildflower biomass $/ \mathrm{m}^{2}(P=0.04)$. Large crabgrass percent cover in the Kentland \#2 experiment did not vary significantly by seedbed preparation treatment (no-till: 67.0 \pm 3.7 , tillage: $62.0 \pm 4.5 ; P=0.4$ )

Eastern Shore. Wildflower and total weed biomass as well as wildflower stem counts were highly variable among farms (Fig. 1). Mean wildflower biomass was significantly greater at farms using tillage plus herbicide $\left(425 \pm 4 \mathrm{~g} \cdot \mathrm{m}^{-2}\right)$ than those using tillage only $\left(111 \pm 49 \mathrm{~g} \cdot \mathrm{m}^{-2}\right)(P=0.01)$. We found no effect of winter cover crop, 3-year previous field-use history, planting date, packing method, time to initial precipitation after planting, or total number of tillage events (Table 3).

Predominant weed species varied greatly among sites. Broad-leaved species included horseweed [Conyza candensis (L.) Cronquist] ( $n=3$ sites), common lambsquarters $(n=1$ site), cutleaf evening primrose (Oenothera laciniata Hill) ( $n=1$ site), and common ragweed (Ambrosia artemisiifolia L.) $(n=2$ sites). Grass species included Johnsongrass [Sorghum halepense (L.) Pers.] ( $n=1$ site), crabgrass (Digitaria sp.) ( $n=3$ sites), and foxtail (Setaria sp.) $(n=1$ site). Horseweed was the predominant broad-leaved weed species in the two tillage-plus-herbicide treatment sites, whereas the predominant weeds at tillage-only sites varied.

Bloom phenology. Mean wildflower blooms peaked in July in both Kentland \#2 and Eastern Shore studies (Fig. 2A and B). Bloom sample period (Kentland \#2: $P<$ 0.0001; Eastern Shore: $P<0.0001)$, species (Kentland \#2: $P=0.0009$; Eastern Shore: $P=$ 0.002 ), and sample period by species interactions (Kentland \#2: $P=0.004$; Eastern Shore: $P<0.0001$ ) were significant for both studies, with significant differences occurring among species blooms most pronounced during July (Fig. 2A and B). Blooms were initially observed in June at Eastern Shore sites and July at Kentland sites. In both studies, black-eyed Susan bloomed most profusely, peaking in July. Maximilian sunflowers bloomed over a longer period in the Eastern Shore plots (July, August, and September) than at Kentland (only July). Partridge pea blooms were observed from July into September in both studies. Both plains coreopsis and Indian blanket blooms were initially observed in June at Eastern Shore sites and in July at Kentland sites and continued to bloom throughout later survey dates. The duration of black-eyed Susan and partridge pea blooms differed between locations: black-eyed Susan blooms persisted into September at Kentland but not on the Eastern Shore, and partridge pea blooms continued into September on the Eastern Shore while they decreased sharply at Kentland during that same time.

\section{Discussion}

Kentland \#1 and Kentland \#2. Greater wildflower establishment occurred after notill herbicide seedbed preparation compared with tillage preparation. This trend differs from previous studies examining wildflower establishment on roadside embankments, which found that either both methods worked equally well (Corley, 1991; Corley et al., 1993), that tillage generated better establishment (Ahern et al., 1992), or that success of tillage relative to no-till was site-dependent (Skousen and Venable, 2008). Moreover, previous research found that wildflower cover was inversely related to weed cover (Skousen and Venable, 2008), whereas we 
Table 1. Means ( $\pm \mathrm{SE})$ of wildflower stem counts, wildflower biomass, and total weed biomass $/ \mathrm{m}^{2}$ by seedbed preparation treatment in two replicated experiments, Kentland \#1 and Kentland \#2.

\begin{tabular}{|c|c|c|c|c|}
\hline & \multicolumn{2}{|c|}{ Kentland \#1 } & \multicolumn{2}{|c|}{ Kentland \#2 } \\
\hline & No-till herbicide & Tillage & No-till herbicide & Tillage \\
\hline Wildflower biomass & $7.55( \pm 2.02)$ & $6.12( \pm 2.81)$ & $17.44( \pm 5.47)$ & $5.28( \pm 1.68)$ \\
\hline
\end{tabular}

${ }^{\mathrm{z}}$ Bolded values indicate significant difference within rows by seedbed preparation $(P<0.05)$, assessed with Student's $t$ tests.

Table 2. Means $( \pm \mathrm{SE})$ of wildflower forb stem counts $/ \mathrm{m}^{2}$ by species and study.

\begin{tabular}{|c|c|c|c|c|c|}
\hline \multirow[b]{2}{*}{ Species } & \multicolumn{2}{|c|}{ Kentland \#1 } & \multicolumn{2}{|c|}{ Kentland \#2 } & \multirow{2}{*}{$\begin{array}{c}\text { Eastern Shore } \\
\text { Overall }\end{array}$} \\
\hline & No-till herbicide & Tillage $^{z}$ & No-till herbicide & Tillage & \\
\hline Chamaecrista fasciculata (A) & $2.24( \pm 0.68) b$ & $2.00( \pm 0.80)$ & $6.00( \pm 0.78) b c$ & $3.63( \pm 0.59) \mathrm{bc}$ & $6.32( \pm 1.40) b c$ \\
\hline Gaillardia pulchella (A) & N/A & N/A & $10.79( \pm 1.27)^{\mathrm{w}} \mathrm{a}$ & $4.08( \pm 0.71) b$ & $2.28( \pm 0.40) \mathrm{cde}$ \\
\hline Rudbeckia hirta (B) & $10.44( \pm 2.52) \mathrm{a}$ & $4.64( \pm 2.60)$ & $11.88( \pm 1.10) \mathrm{a}$ & $11.29( \pm 1.55) \mathrm{a}$ & $13.20( \pm 1.96) \mathrm{a}$ \\
\hline Coreopsis lanceolata $(\mathrm{P})$ & $0.44( \pm 0.44) b$ & $0.68( \pm 0.36)$ & $0.33( \pm 0.19) \mathrm{d}$ & $0.04( \pm 0.04) \mathrm{d}$ & $3.12( \pm 0.80) \mathrm{cde}$ \\
\hline Echinacea purpurea $(\mathrm{P})$ & $2.00( \pm 0.68) b$ & $2.44( \pm 0.88)$ & $2.63( \pm 0.46) \mathrm{cd}$ & $1.96( \pm 0.59) \mathrm{bcd}$ & $3.80( \pm 0.80) \mathrm{cde}$ \\
\hline Pycnanthemum tenuifolium $(\mathrm{P})$ & $0.00( \pm 0.00) \mathrm{b}$ & $0.00( \pm 0.00)$ & $0.25( \pm 0.17) \mathrm{d}$ & $0.04( \pm 0.04) \mathrm{d}$ & $0.00( \pm 0.00) \mathrm{e}$ \\
\hline
\end{tabular}

${ }^{\mathrm{z}}$ There were no significant differences among wildflower stem counts in the Kentland \#1 tillage treatment.

${ }^{\mathrm{y}}$ Forb species life form indicated: $(\mathrm{A})=$ annual; $(\mathrm{B})=$ biennial; or $(\mathrm{P})=$ perennial.

${ }^{\mathrm{x}}$ Values within the same column by study are not significantly different when marked by the same letter, analyzed by Tukey-Kramer honestly significant difference tests $(P<0.05)$.

${ }^{\mathrm{w}}$ Bolded values indicate significant differences of species mean count by seedbed preparation $(P<0.05)$, assessed with Student's $t$ tests.

$\mathrm{N} / \mathrm{A}=$ not available.

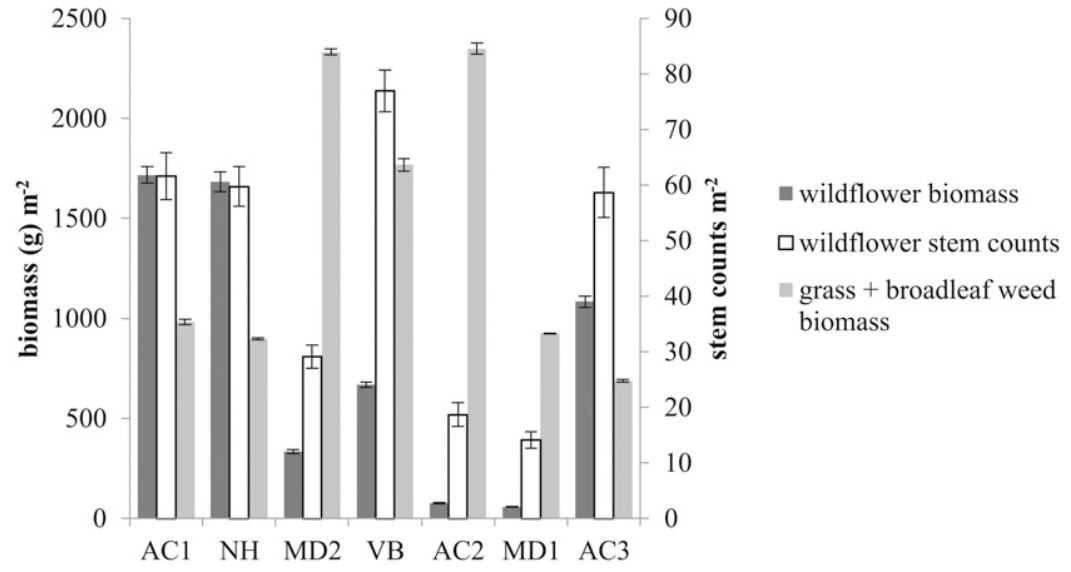

Fig. 1. Mean wildflower and total weed biomass $/ \mathrm{m}^{2}$, and mean wildflower stem counts $/ \mathrm{m}^{2}$ by farm in the Eastern Shore study. Error bars represent standard error calculations. Each farm abbreviation corresponds to complete site descriptions in Supplemental Figure 1 and Supplemental Table 3. $\mathrm{MD} 1$ and $\mathrm{MD} 2$ = Maryland farm sites; $\mathrm{AC} 1, \mathrm{AC} 2, \mathrm{AC} 3$ = Accomack County, Virginia farm sites; $\mathrm{NH}=$ Northampton County, Virginia farm site; $\mathrm{VB}=$ Virginia Beach farm site.

found more weeds and more wildflowers in no-till than in tilled plots. The soil at our study sites is arable farmland, and likely of higher quality for overall plant growth than that found along roadsides. The possibility exists that fewer nutritional constraints on farmland relative to roadside embankments could reshape weed-wildflower competition dynamics (Gleeson and Tilman, 1990); on farmland, weed competition might not always be the primary driver of wildflower establishment success.

This research showed that there was no correlation, for the species examined, between seed mass and the effects of tillage on wildflower establishment. This was in contrast to our original hypothesis that small seeded species would get buried in tilled soil and not establish well. The Kentland studies showed that wildflower growth of all species was generally greater in no-till compared with tilled seedbeds. This suggests that tillage did not cause smaller seeds to settle too deeply in soil for germination, and that our preseeding packing methodology functioned adequately to firm up post-tillage soil. There may be other possible side effects of tillage that could detrimentally affect all species; for example, there can be increased erosion during wind and rain, or a detrimental hard crust may form when tilled soil dries after a rain event (Lal et al., 2007). However, the exact mechanisms driving greater wildflower establishment after no-till in our studies remain unclear.

The increased common lambsquarters and hairy galinsoga pressure observed after tillage preparation in Kentland \#1 and Kentland \#2 experiments, respectively, supports prior evidence for greater annual broad-leaved weed growth under tillage than under a notill regime (Derksen et al., 1993; FroudWilliams et al., 1981). We hypothesize that common lambsquarters did not reach densities high enough in our study to inhibit wildflower growth; however, there was evidence that hairy galinsoga may have affected wildflower establishment in tilled seedbeds in the Kentland \#2 study ( $\mathrm{Fu}$ and Ashley, 2006; Warwick and Sweet, 1983). Sites with a history of high annual broad-leaved weed pressures might consider a no-till seedbed preparation rather than tillage before pollinator habitat installation. We did not see treatment effects manifest in different levels of perennial or wind-dispersed weed growth after tillage vs. no-till preparations. These types of weeds have been associated with notill practices (Derksen et al., 1993; FroudWilliams et al., 1981; Menalled et al., 2001; Tuesca et al., 2001; Wrucke and Arnold, 1985; Zanin et al., 1997), and may become more of a problem in wildflower habitats in future years.

The high weed pressures measured across our studies during this first year of establishment are not necessarily indicative of failure in future years. A study of roadside meadow establishment found that first-year weed density did not affect ultimate establishment success if weeds were controlled well enough for perennial wildflowers to survive (Love et al., 2016). Another study found that second-year roadside wildflower coverage 
Table 3. Results of independent general linear models assessing effects of environmental and management factors on wildflower stem counts, wildflower biomass, and total weed biomass in the Eastern Shore study.

\begin{tabular}{|c|c|c|c|}
\hline & Wildflower stem counts & Wildflower biomass & Total weed biomass \\
\hline Seedbed preparation (tillage + herbicide, tillage only) & $P=0.13, \chi^{2}=2.28, \mathrm{df}=1$ & $P=0.010, \chi^{2}=6.62, \mathrm{df}=1^{\mathrm{z}}$ & $P=0.99, \chi^{2}=0.13, \mathrm{df}=1$ \\
\hline Winter cover crop (presence or absence) & $P=0.52, \chi^{2}=0.42, \mathrm{df}=1$ & $P=0.86, \chi^{2}=0.030, \mathrm{df}=1$ & $P=0.17, \chi^{2}=1.89, \mathrm{df}=1$ \\
\hline 3-year field history (\# years cropped: $0,1,2$, or 3 ) & $P=0.32, \chi^{2}=2.29, \mathrm{df}=2$ & $P=0.12, \chi^{2}=4.25, \mathrm{df}=2$ & $P=0.21, \chi^{2}=3.13, \mathrm{df}=2$ \\
\hline Planting date (\# days relative to first planting) & $P=0.43, \chi^{2}=0.62, \mathrm{df}=1$ & $P=0.73, \chi^{2}=0.12, \mathrm{df}=1$ & $P=0.92, \chi^{2}=0.011, \mathrm{df}=1$ \\
\hline Time to initial precipitation after planting & $P=0.54, \chi^{2}=0.38, \mathrm{df}=1$ & $P=0.72, \chi^{2}=0.13, \mathrm{df}=1$ & $P=0.19, \chi^{2}=1.69, \mathrm{df}=1$ \\
\hline Total number of tillage events & $P=0.67, \chi^{2}=0.18, \mathrm{df}=1$ & $P=0.071, \chi^{2}=3.27, \mathrm{df}=1$ & $P=0.15, \chi^{2}=2.06, \mathrm{df}=1$ \\
\hline Packing method (cultipacker or roller) & $P=0.91, \chi^{2}=0.013, \mathrm{df}=1$ & $P=0.19, \chi^{2}=1.74, \mathrm{df}=1$ & $P=0.97, \chi^{2}=0.0014, \mathrm{df}=1$ \\
\hline
\end{tabular}

${ }^{\mathrm{z}}$ Bolded values indicate significance $(P<0.05)$.
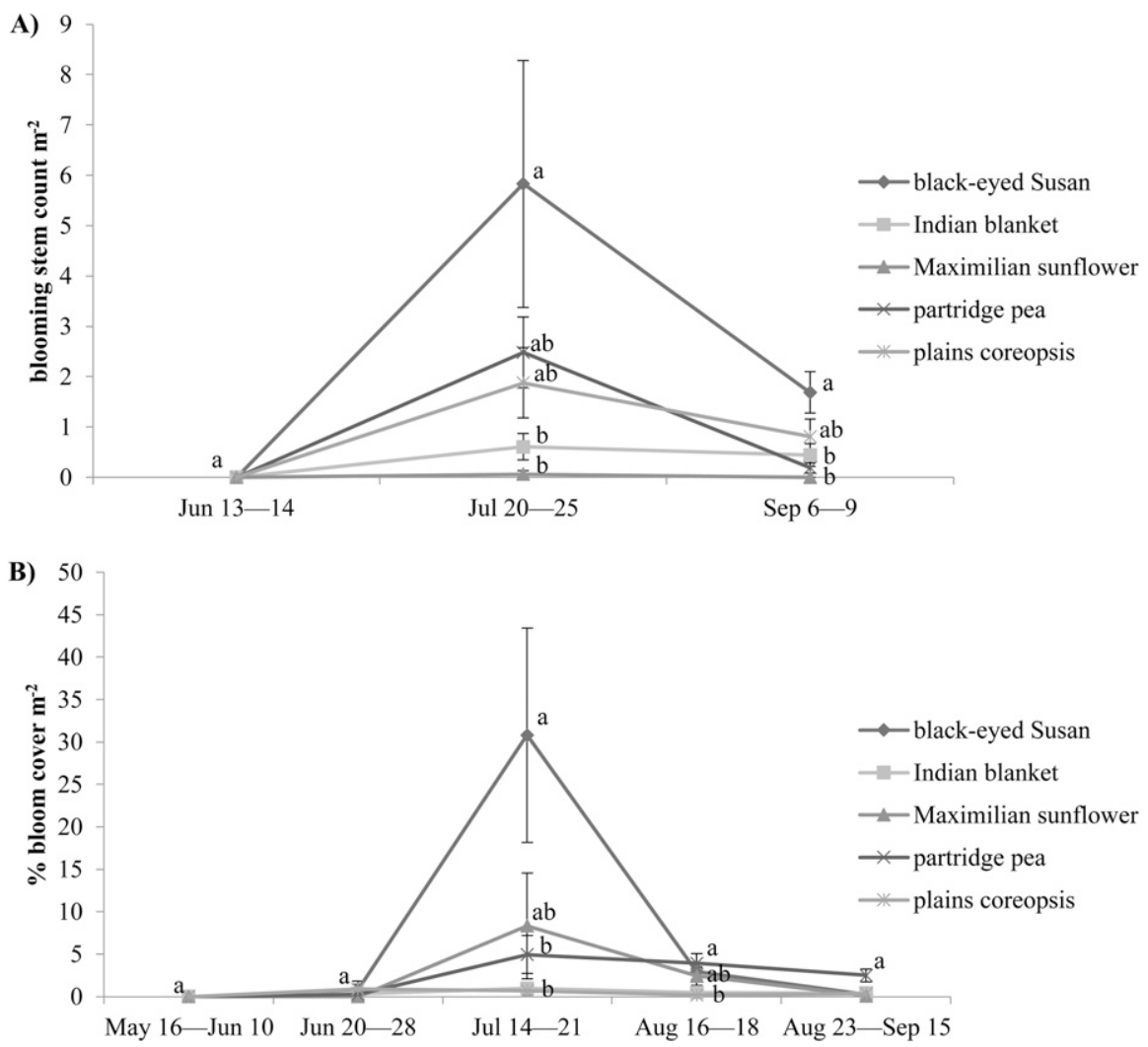

Fig. 2. Bloom phenology of wildflower annual or biennial species across survey dates: (A) mean bloom stem count $/ \mathrm{m}^{2}$ values $( \pm \mathrm{SE})$ are shown for the Kentland \#2 experiment, (B) mean bloom percent cover $/ \mathrm{m}^{2}$ values are shown $( \pm \mathrm{SE})$ for the Eastern Shore experiment. Different letters denote significant differences in blooms among species during each individual sample period $(P<0.05$ according to Tukey-Kramer honestly significant difference tests).

was as high as $45 \%$ after a poor first-year establishment that had less than $10 \%$ wildflower coverage after a tillage seedbed preparation (Skousen and Venable, 2008). Thus, despite the high weed pressures and high variability of wildflower establishment during the first year after planting, the wildflower plots studied will likely become acceptably established in future years. It is unclear whether differences in weed pressures and establishment success during the first year will propagate in subsequent years.

Eastern Shore. There was a large degree of variability among Eastern Shore farms, making it difficult to identify patterns underlying wildflower establishment success and weed pressure. Sites using tillage-plusherbicide seedbed preparation established significantly more wildflowers than sites using tillage-only preparation. However, in early, mid, and late season (Vaughan and Skinner, 2015). Providing floral resources throughout the entire season is thought to be important because of varying native pollinator phenology (Gill et al., 2014; Minckley et al., 1994; Roulston and Goodell, 2011). However, customizing wildflower mixes to complement the phenology of existing floral resources may better conserve pollinators and reverse pollination declines than mixes that bloom uniformly throughout the growing season (Robson, 2014; Venturini et al., 2017). In agricultural landscapes, floral resource availability is often driven by tree fruit blooms early season, bramble (Rubus spp.) and vegetable (e.g., squash and tomato) blooms midseason (Kallioniemi et al., 2017; Leong et al., 2016; Mallinger et al., 2016; Todd et al., 2016; Venturini et al., 2017; Williams et al., 2012), and mass flowering crops (e.g., spring canola, sunflower, alfalfa) late season. In natural or seminatural landscapes, floral resources tend to concentrate in the early season (Leong et al., 2016; Williams et al., 2012), although some common species provide midseason [e.g., brambles, milkweed (Asclepias spp.), vetch (Vicia spp.)] or lateseason [goldenrod (Solidago spp.), asters (Symphyotrichum spp.)] blooms. In urban landscapes, the focus is usually on midseason blooms (Leong et al., 2016; Wray and Elle, 2015). In this research, the landscapes surrounding our study sites were predominantly agricultural field crops, seminatural areas, and wetlands with midseason blooms being most scarce. Bloom phenology in Kentland \#2 and Eastern Shore study sites exhibited a pronounced midsummer peak in 2016, which complemented low floral resource availability in the surrounding landscape.

One of the many considerations in designing pollinator habitat seed mixtures is the ratio of annual and perennial species. Our plant mixes contained both perennial and annual species. There is preliminary evidence that perennial wildflowers tend to provide greater nectar and pollen provisions and earlier spring bloom availability than annuals (Hicks et al., 2016). However, the relatively rapid growth of annual wildflowers may better compete with annual weed growth than perennial wildflowers, functioning like a living mulch (Teasdale, 1996). In addition, the visual confirmation of first-year blooms may enhance farmer motivation, which is a critical factor affecting the successful outcome of pollinator habitat installations (McCracken et al., 2015). As perennial wildflowers become 
established in future years, the number of flowers and duration of blooms should increase. To assess the contribution of established wildflower plots to pollinator conservation, more frequent bloom counts will be beneficial.

\section{Conclusions}

Total wildflower establishment was greater after a no-till-plus-herbicide seedbed preparation than a tillage only preparation in replicated experiments and almost every individual wildflower species followed this same trend. In on-farm trials, total wildflower establishment was greater after tillage-plusherbicide than tillage-only seedbed preparations. The effects of seedbed preparation on weed growth were highly site dependent, and total weed growth was not predictive of wildflower establishment. There were more common lambsquarters and hairy galinsoga weeds in till than in no-till plots, whereas there was more hairy vetch, which had previously been planted as a cover crop, in notill plots. While the effects of different seedbed preparation techniques were measurable, there was still a large amount of unexplained variability in wildflower and weed growth, as well as in predominating weed species, across treatment sites. More peerreviewed research is needed to support USDA's pollinator habitat cost-share programs to better ensure the success of habitat establishment under a range of site conditions and management histories. Moreover, to effectively expand pollinator habitats and conserve pollinators nationwide (Vilsack and McCarthy, 2015), more work needs to be done to design native wildflower seed mixtures that are cost-effective, are of high value to pollinators, and complement the timing of existing bloom resources.

\section{Literature Cited}

Ahern, J., C. Niedner, and A. Barker. 1992. Roadside wildflower meadows: Summary of benefits and guidelines to successful establishment and management. National Research Council.

Aldrich, J.H. 2002. Factors and benefits in the establishment of modest-sized wildflower plantings: A review. Native Plants J. 3:67-86.

Bartels, E. 1992. Restoring the northeastern meadow + site preparation and planting techniques. Landscape Architecture 82:74-77.

Chauhan, B., G. Gill, and C. Preston. 2006. Tillage system effects on weed ecology, herbicide activity and persistence: A review. Anim. Prod. Sci. 46:1557-1570.

Corley, W. 1991. Seedbed preparation alternatives for establishment of wildflower meadows and beauty spots. SNA Res. Conf. Proc. 36:280281.

Corley, W., T. Murphy, and K. Reynolds. 1993. Weed management options for wildflower meadows and beauty spots. SNA Res. Conf. Proc. 38:315-316.

Derksen, D.A., G.P. Lafond, A.G. Thomas, H.A. Loeppky, and C.J. Swanton. 1993. Impact of agronomic practices on weed communities: Tillage systems. Weed Sci. 41:409-417.
Froud-Williams, R.J., R.J. Chancellor, and D.S.H. Drennan. 1981. Potential changes in weed floras associated with reduced-cultivation systems for cereal production in temperate regions. Weed Res. 21:99-109.

FSA. 2013. CP42 Pollinator Habitat: Establishing and supporting diverse pollinator-friendly habitat. United States Department of Agriculture (USDA), Farm Service Agency (FSA), Washington, DC.

$\mathrm{Fu}, \mathrm{R}$. and R.A. Ashley. 2006. Interference of large crabgrass (Digitaria sanguinalis), redroot pigweed (Amaranthus retroflexus), and hairy galinsoga (Galinsoga ciliata) with bell pepper. Weed Sci. 54:364-372.

Gill, K.A., R. Cox, and M.E. O’Neal. 2014. Quality over quantity: Buffer strips can be improved with select native plant species. Environ. Entomol. 43:298-311.

Gleeson, S.K. and D. Tilman. 1990. Allocation and the transient dynamics of succession on poor soils. Ecology 71:1144-1155.

Hicks, D.M., P. Ouvrard, K.C. Baldock, M. Baude, M.A. Goddard, W.E. Kunin, N. Mitschunas, J. Memmott, H. Morse, and M. Nikolitsi. 2016. Food for pollinators: Quantifying the nectar and pollen resources of urban flower meadows. PLoS One 11:e0158117.

Howell, E.A. and V.M. Kline. 1992. The role of competition in the successful establishment of selected prairie species

Hyder, D.N., F.A. Sneva, and W. Sawyer. 1955. Soil firming may improve range seeding operations. J. Range Mgt. 8:159-163.

SAS Institute Inc. 2016. JMP Pro Version 12. SAS Institute Inc., Cary, NC.

Kallioniemi, E., J. Åström, G.M. Rusch, S. Dahle, S. Åström, and J.O. Gjershaug. 2017. Local resources, linear elements and mass-flowering crops determine bumblebee occurrences in moderately intensified farmlands. Agr. Ecosyst. Environ. 239:90-100.

Knezevic, S.Z., S.P. Evans, E.E. Blankenship, R.C. Van Acker, and J.L. Lindquist. 2002. Critical period for weed control: The concept and data analysis. Weed Sci. 50:773-786.

Lal, R., D. Reicosky, and J. Hanson. 2007. Evolution of the plow over 10,000 years and the rationale for no-till farming. Soil Tillage Res. 93:1-12.

Leong, M., L.C. Ponisio, C. Kremen, R.W. Thorp, and G.K. Roderick. 2016. Temporal dynamics influenced by global change: Bee community phenology in urban, agricultural, and natural landscapes. Glob. Change Biol. 22:1046-1053.

Love, S.L., P.J. Hutchinson, and W.J. Price. 2016. Managing weeds during wildflower meadow establishment in the arid Intermountain West Efficacy of a grass-first strategy for sites with heavy annual weed pressure. Native Plants J. 17:216-229.

Mallinger, R.E., J. Gibbs, and C. Gratton. 2016. Diverse landscapes have a higher abundance and species richness of spring wild bees by providing complementary floral resources over bees' foraging periods. Landsc. Ecol. 31:15231535.

Martin, L.C. 1986. The wildflower meadow book. East Woods Press, Charlotte, NC.

McCracken, M.E., B.A. Woodcock, M. Lobley, R.F. Pywell, E. Saratsi, R.D. Swetnam, S.R Mortimer, S.J. Harris, M. Winter, and S. Hinsley. 2015. Social and ecological drivers of success in agri-environment schemes: The roles of farmers and environmental context. J. Appl. Ecol. 52:696-705.

Menalled, F.D., K.L. Gross, and M. Hammond 2001. Weed aboveground and seedbank community responses to agricultural management systems. Ecol. Appl. 11:1586-1601.

Minckley, R.L., W.T. Wcislo, D. Yanega, and S.L. Buchmann. 1994. Behavior and phenology of a specialist bee (Dieunomia) and sunflower (Helianthus) pollen availability. Ecology 75:1406-1419.

Monsen, S.B. and R. Stevens. 2004. Chapter 12. Seedbed preparation and seeding practices, p. 121-154. In: S.B. Monsen, R. Stevens, and N.L. Shaw (eds.). Restoring western ranges and wildlands, Vol. 1. U.S. Department of Agriculture, Forest Service, Rocky Mountain Research Station, Fort Collins, CO.

Norcini, J.G. and J.H. Aldrich. 2004. Establishment of native wildflower plantings by seed. University of Florida Cooperative Extension Service, Institute of Food and Agricultural Sciences, EDIS.

NRCS. 2007. Conservation cover (327a): Virginia conservation practice VA job sheet. United States Department of Agriculture (USDA), Washington, DC.

NRCS. 2012. Conservation cover (327): Maryland herbaceous plantings for pollinator habitat. United States Department of Agriculture (USDA), Washington, DC.

Oegema, T. and R.A. Fletcher. 1972. Factors that influence dormancy in milkweed seeds. Can. J. Bot. 50:713-718.

Perry, L.P. 2005. Successful wildflower meadows. University of Vermont, Burlington, VT.

Robson, D.B. 2014. Identification of plant species for crop pollinator habitat enhancement in the northern prairies. J. Pollinat. Ecol. 14:218234.

Roulston, T.H. and K. Goodell. 2011. The role of resources and risks in regulating wild bee populations. Annu. Rev. Entomol. 56:293-312.

Skousen, J.G. and C. Venable. 2008. Establishing native plants on newly-constructed and olderreclaimed sites along West Virginia highways. Land Degrad. Dev. 19:388-396.

Teasdale, J.R. 1996. Contribution of cover crops to weed management in sustainable agricultural systems. J. Prod. Agr. 9:475-479.

Todd, K.J., M.M. Gardiner, and E.D. Lindquist. 2016. Mass flowering crops as a conservation resource for wild pollinators (Hymenoptera: Apoidea). J. Kans. Entomol. Soc. 89:158-167.

Tuesca, D., E. Puricelli, and J. Papa. 2001. A longterm study of weed flora shifts in different tillage systems. Weed Res. 41:369-382.

Vaughan, M., E. Mäder, J.K. Cruz, J. GoldenetzDollar, K. Gill, and B. Borders. 2014. Conservation cover (327) for pollinators: Pennsylvania installation guide and job sheet. The Xerces Society for Invertebrate Conservation, Portland, OR.

Vaughan, M., E. Mäder, J. Guisse, J. GoldenetzDollar, B. Borders, and K. Gill. 2013. Conservation cover (327) for pollinators: New Jersey installation guide and job sheet. The Xerces Society for Invertebrate Conservation, Portland, OR.

Vaughan, M. and M. Skinner. 2008. Using farm bill programs for pollinator conservation. USDANRCS National Plant Data Center. $<$ http://www.xerces.org/wp-content/uploads/ 2008/11/using_farm_bill_programs_xerces_ society.pdf>.

Vaughan, M. and M. Skinner. 2015. Using 2014 farm bill programs for pollinator conservation, biology technical note no. 78, 2nd ed. United States Department of Agriculture (USDA), Washington, DC.

Venturini, E.M., F.A. Drummond, A.K. Hoshide, A.C. Dibble, and L.B. Stack. 2017. Pollination 
reservoirs for wild bee habitat enhancement in cropping systems: A review. Agroecol. Sust. Food Syst. 41:101-142.

Vilsack, T. and G. McCarthy. 2015. National strategy to promote the health of honey bees and other pollinators. Report Issued by the White House the Pollinator Health Task Force on 19.

Warwick, S.I. and R.D. Sweet. 1983. The biology of Canadian weeds: 58. Galinsoga parviflora and $G$. quadriradiata (= G. ciliata). Can. J. Plant Sci. 63:695-709.
Williams, N.M., J. Regetz, and C. Kremen. 2012. Landscape-scale resources promote colony growth but not reproductive performance of bumble bees. Ecology 93:1049-1058.

Wilson, J.W. 1992. Landscaping with wildflowers: An environmental approach to gardening. Houghton Mifflin Harcourt Publishing Company, Boston, MA.

Wray, J.C. and E. Elle. 2015. Flowering phenology and nesting resources influence pollinator community composition in a fragmented ecosystem. Landsc. Ecol. 30:261-272.
Wrucke, M.A. and W.E. Arnold. 1985. Weed species distribution as influenced by tillage and herbicides. Weed Sci. 33:853-856.

Yenish, J.P., T.A. Fry, B.R. Durgan, and D.L. Wyse. 1996. Tillage effects on seed distribution and common milkweed (Asclepias syriaca) establishment. Weed Sci. 44:815820 .

Zanin, G., S. Otto, L. Riello, and M. Borin. 1997. Ecological interpretation of weed flora dynamics under different tillage systems. Agr. Ecosyst. Environ. 66:177-188. 

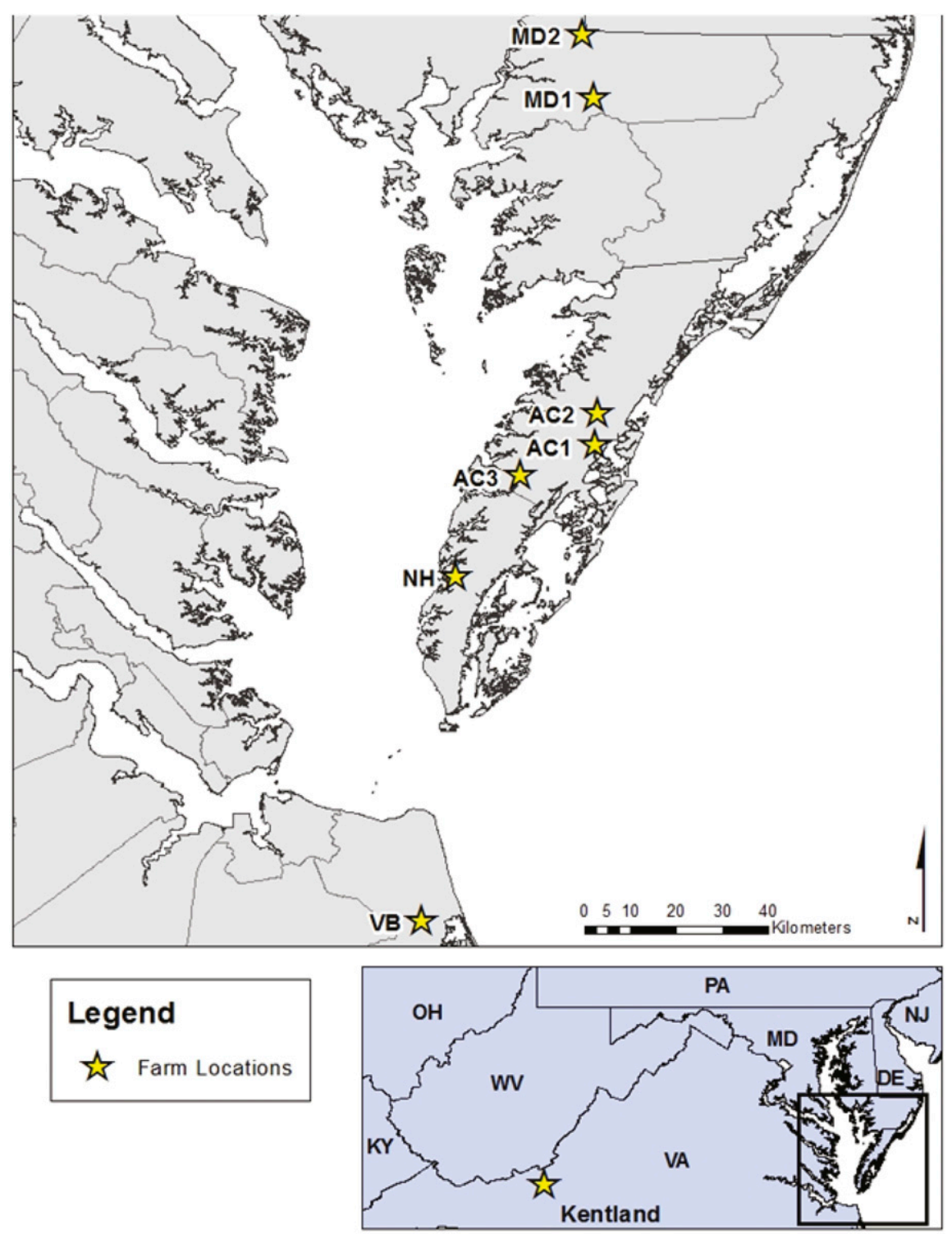

Supplemental Fig. 1. Map of Kentland and Eastern Shore study site locations. 


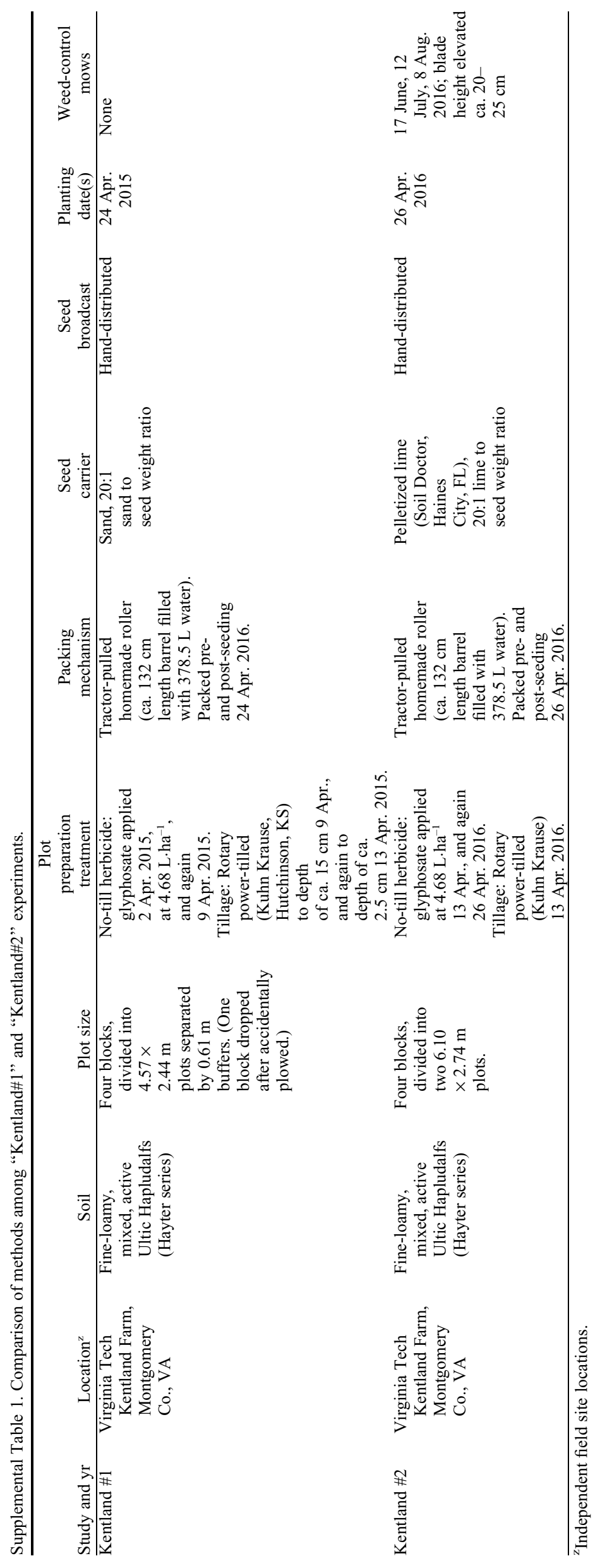




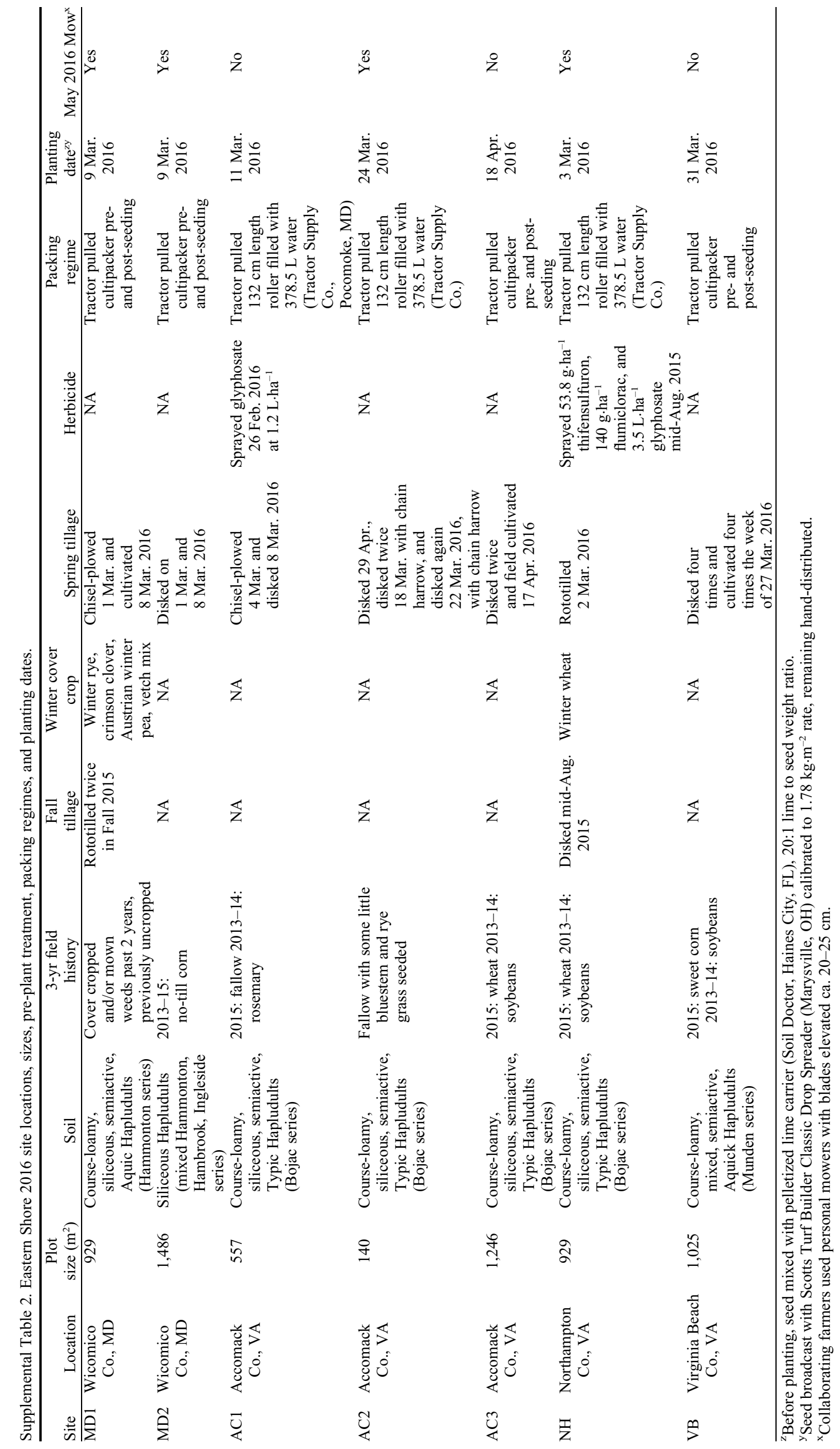




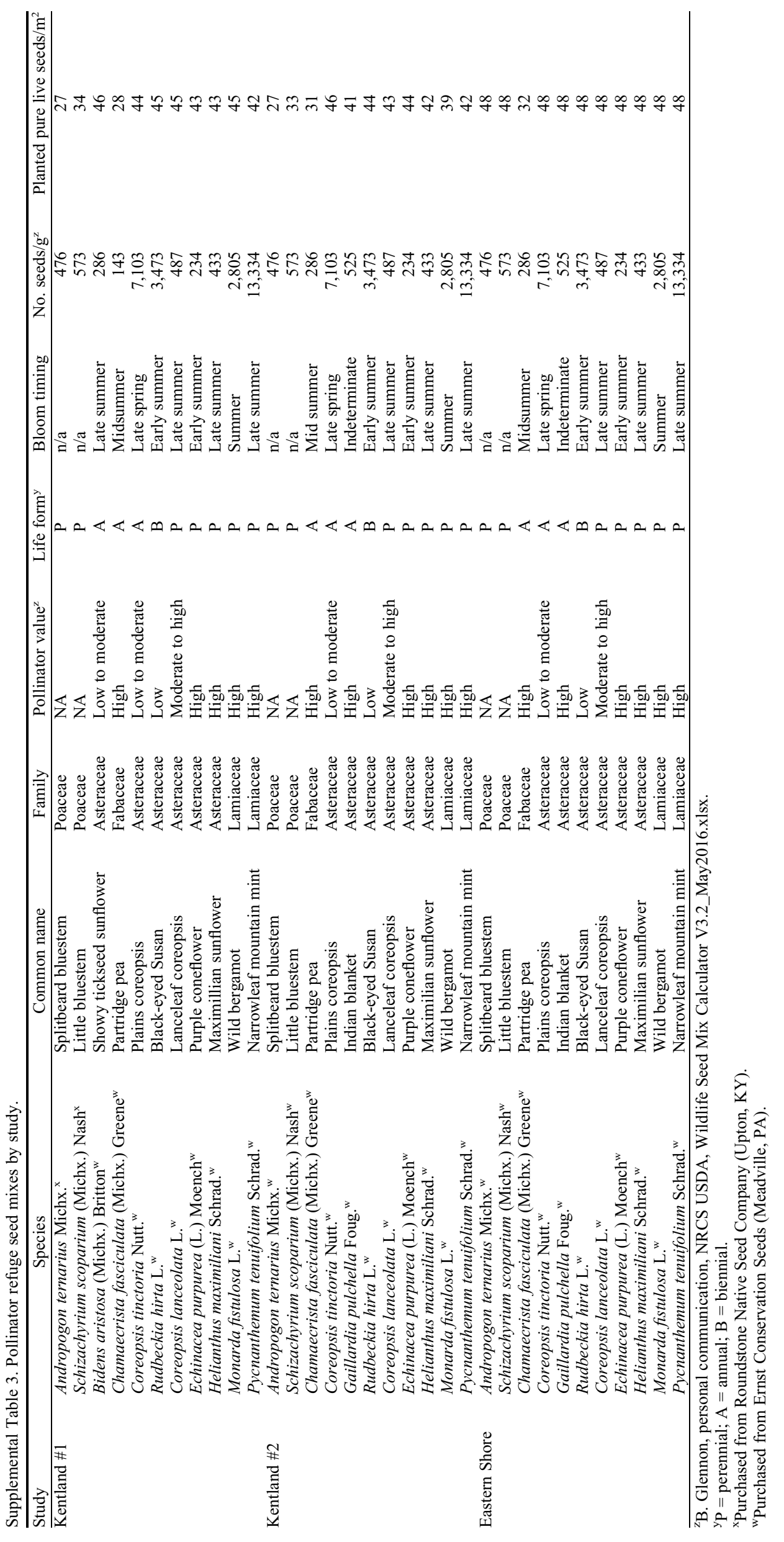

